\title{
Liga de Defesa Popular: a construção de um espaço de luta política entre os trabalhadores organizados de Porto Alegre após a Greve Geral de 1917
}

\author{
Frederico Duarte Bartz*
}

Resumo: O artigo analisa a formação e o desenvolvimento da Liga de Defesa Popular de Porto Alegre, organismo criado em 1917 para coordenar a Greve Geral que foi deflagrada naquele ano. A LDP foi criada sob a influência de militantes anarquistas, mas, após o final do movimento grevista, acabou se tornando um espaço para que os sindicalistas reformistas que dirigiam a Federação Operária, aliados a membros do Partido Republicano, estendessem sua influência sobre os trabalhadores organizados da capital gaúcha. Como a LDP era uma frente ampla, posteriormente a organização também serviu para que os militantes anarquistas atacassem os sindicalistas reformistas e retomassem o controle da Federação. Dessa forma, a Liga vai ser entendida neste texto como um espaço de luta política em que os militantes de Porto Alegre disputaram a hegemonia sobre o movimento operário e o controle sobre suas associações.

Palavras-chave: Greve Geral de 1917; anarquismo; sindicalismo reformista.

\begin{abstract}
The article analyzes the formation and development League for the Defense of People's Porto Alegre (LDP), an organization created in 1917 to coordinate the general strike that broke out that year. The LDP was created under the influence of anarchist militants, but after the end of the strike movement, the League became a space for reformist syndicalists who ran the Workers' Federation, together with the Republican Party members, hold out their influence on organized workers of the state capital. As the LDP was a broad front, later this organization also served to the anarchist militants attack the reformist syndicalists and retake control of the Federation. Thus, the League will be understood in this article as a political battlefield, where militants from Porto Alegre faught for hegemony over the labor movement and control over their associations.
\end{abstract}

Keywords: strike of 1917; anarchism; reformist syndicalism.

* Doutor em História pela Universidade Federal do Rio Grande do Sul (UFRGS). Técnico em assuntos educacionais na UFRGS. 


\section{Introdução}

A Liga de Defesa Popular, também conhecida como LDP, foi uma das mais importantes associações operárias surgidas em Porto Alegre no período das grandes greves da Primeira República. O seu aparecimento está intimamente ligado à Greve Geral de 1917, em Porto Alegre, quando a associação foi formada para gerir a paralisação dos trabalhadores. Depois da greve, no entanto, a LDP não desapareceu, mas passou por uma institucionalização tornando-se um canal de comunicação entre os trabalhadores organizados e o poder municipal. O fato é que, as características dessa entidade favoreceram uma tendência a tornar a Liga um campo de disputa pela hegemonia do movimento operário entre sindicalistas anarquistas e reformistas.

Até o presente momento, a pesquisa que analisou de forma minuciosa a Liga de Defesa Popular foi a dissertação de Adhemar Lourenço da Silva Júnior, Povo! Trabalhadores! tumultos e movimento operário (estudo centrado em Porto Alegre), de 1994, em que um dos movimentos enfocados pelo autor é a greve de 1917, que resultou na fundação da associação'. Outro estudo que descreve a greve e a formação da LDP, mas sob a perspectiva de um primeiro ensaio de aproximação do poder do Estado com os trabalhadores, é o livro de Miguel Bodea A greve geral de 1917 e as origens do trabalhismo gaúcho, de 1979.²

Em um período mais recente, César Bubolz Queirós também analisou a Liga de Defesa Popular em sua tese de doutorado Estratégias e identidades: relações entre governo estadual, patrões e trabalhadores nas grandes greves da primeira república em Porto Alegre (1917-1919), defendida em 2012. ${ }^{3}$ Sua análise do período se dedica ao estudo das relações dos trabalhadores com o Estado e a burguesia estadual, mas também se dedica a analisar as disputas políticas dentro do campo do sindicalismo. Em um artigo publicado em 2014 intitulado A Greve Geral de 1918 $e$ as disputas pela hegemonia política nas associações operárias em Porto Alegre, Queirós se dedica a analisar mais especificamente o conteúdo político da disputa pela liderança das associações operárias, mas seu foco recai sobre a greve de 1918, não abarcando uma análise mais de fôlego sobre a Liga de Defesa Popular. ${ }^{4}$

Os primeiros trabalhos citados encerram o estudo da Liga nos meses que se seguiram à greve, pois havia poucas informações sobre ela depois disso. A tese e o artigo de Queirós trazem a análise para os períodos posteriores, já que sua tese abarcou as três grandes greves ocorridas em Porto Alegre; mesmo assim a LDP não aparece como um fenômeno autônomo em sua análise (como também não aparecia em Bodea ou Silva Jr.). A partir de pesquisas em fontes como o jornal A Luta, de 1918, se percebe que a Liga de Defesa Popular teve uma existência complexa e um papel fundamental na reorganização do movimento operário da capital gaúcha. Partindo dos fatos expostos pelos trabalhos já escritos

1 SILVA JR., Adhemar Lourenço. "Povo! Trabalhadores!: tumultos e movimento operário (estudo centrado em Porto Alegre, 1917)". (Dissertação de mestrado em História, Universidade Federal do Rio Grande do Sul, 1994).

2 BODEA, Miguel. A greve geral de 1917 e as origens do trabalhismo gaúcho: ensaio sobre o pré-ensaio de poder de uma elite política dissidente a nível nacional. Porto Alegre: L\&PM, 1979.

3 QUEIRÓS, César Augusto Bubolz. "Estratégias e identidades: relações entre governo estadual, patrões e trabalhadores nas grandes greves da primeira república em Porto Alegre (1917/1919)". (Tese de doutorado em História, Universidade Federal do Rio Grande do Sul, 2012).

4 QUEIRÓS, César Augusto Bubolz. "A Greve Geral de 1918 e as disputas pela hegemonia política nas associações operárias em Porto Alegre". Fronteiras do Tempo: Revista de Estudos Amazônicos, Manaus, n. 5, 2014. 
sobre a greve de 1917 e levando em conta as novas informações que as fontes expõem, pretendo analisar a atuação da LDP para além do ano de sua fundação e do movimento paredista no qual isto se deu; além disso, também desejo expor algumas hipóteses ligando as funções exercidas por essa associação com um novo panorama que se inaugura posteriormente em Porto Alegre, caracterizado por uma predominância dos anarquistas e pela radicalização do movimento operário.

Nesse sentido, minha análise vai privilegiar o aspecto político que a LDP tomou, mostrando que naquele momento específico a formação desse campo de disputa política foi fundamental para orientar a ação dos militantes operários em Porto Alegre.

\section{A Greve Geral de 1917 e a formação da Liga de Defesa Popular}

O período de 1917 a 1920 é considerado o momento de mais intensa mobilização por parte das organizações operárias na Primeira República. As grandes mobilizações e a intensificação de lutas por bandeiras históricas como as oito horas de trabalho, ou por novos objetivos como a articulação de uma insurreição operária, fizeram com que o movimento alcançasse uma posição de destaque na vida política dos principais centros urbanos do país. No Rio Grande do Sul, as mobilizações começaram em março de 1917 com a greve dos calceteiros e canteiros de Porto Alegre, que acabou sendo violentamente reprimida. ${ }^{5} \mathrm{O}$ movimento mais intenso e organizado, entretanto, ocorreu no inverno daquele ano, no mês de agosto mais precisamente. Naquele momento, a principal associação operária do estado, que era a Federação Operária do Rio Grande do Sul (FORGS), estava desarticulada e não tinha uma atuação destacada entre os trabalhadores. Esse panorama era bem diferente da situação existente no começo dos anos 1910, quando os operários anarquistas substituíram os socialistas na direção da FORGS e figuras importantes dos dois grupos se digladiaram pelas páginas dos jornais da imprensa operária. ${ }^{6}$ Também era diferente do início da Primeira Guerra Mundial, quando a Federação Operária fez incursões de propaganda ao interior, levou adiante uma campanha antimilitarista e promoveu atividades culturais intensas. As principais figuras do anarquismo em Porto Alegre, os militantes Cecílio Villar, Polidoro Santos, Nino e Orlando Martins, estavam fora da Federação. Por outro lado, a maior liderança do socialismo rio-grandense, Francisco Xavier da Costa, também se afastara da luta sindical: havia aderido ao Partido Republicano e se tornara Conselheiro Municipal de Porto Alegre.?

Para tentar retomar influência dentro da FORGS e mobilizar a classe trabalhadora, os anarquistas reativaram a União Operária Internacional (UOI), a mais tradicional sociedade dos libertários na capital em julho de 1917, preparando uma mobilização contra a carestia de vida. Para Adhemar Lourenço da Silva Júnior

"A União se reorganizou no começo de julho com membros de diversas categorias

5 Sobre essa greve e as articulações dos trabalhadores em pedra de Porto Alegre com outras regiões do país e da América do Sul, ver SILVA Jr. Adhemar Lourenço da. "Os sindicatos na idade da pedra". Acervo, Rio de Janeiro, v. 15, n. 1, jan.jun. 2002.

6 BILHÃO, Isabel. Rivalidades e Solidariedades no Movimento Operário: Porto Alegre (1906-1911). Porto Alegre: EDIPUCRS, 1999, p. 67-108.

7 Para a aproximação de Xavier com o PRR ver SCHMIDT, Benito Bisso. Em busca da terra da promissão: a história de dois líderes socialistas. Porto Alegre: Palmarinca, 2004. 
para se constituir em oposição à administração da FORGS". ${ }^{8}$ Os operários já haviam declarado greve por causa da carestia de vida em Curitiba e em São Paulo e, nesta última cidade, organizaram um Comitê de Defesa Proletária. Essa associação popular, dirigida principalmente por anarquistas, nasceu para organizar a greve na capital paulista. Nessa cidade, a paralisação mobilizou um grande número de trabalhadores e o referido comitê tentou unificar os trabalhadores em torno de propostas comuns que atendessem também às classes populares. ${ }^{9}$

Enquanto os anarquistas se movimentavam em Porto Alegre, era eleita, no âmbito da FORGS, uma diretoria onde os principais nomes eram militantes pouco conhecidos, como Ezequiel Oliveira para secretário e José Dias para tesoureiro. A União Operária Internacional se empenhava pela deflagração de uma greve em Porto Alegre, mas a FORGS não se comprometeu com tal ação. No dia 29 de julho de 1917, aconteceu uma reunião na Federação para decidir pela greve, mas o encontro não foi comandado pelos dirigentes da FORGS, mas pelos da UOI. O resultado do encontro foi a convocação de uma greve geral, mas não pela FORGS ou pela UOI, mas por um organismo criado ad hoc: a Liga de Defesa Popular. Essa organização estava fora da Federação Operária do Rio Grande do Sul e seria o comitê que comandaria as movimentações resultantes da greve. ${ }^{10}$

Mesmo que a LDP não se confundisse com a Federação, ela mantinha uma ligação com ela, pelo menos em termos de origem. Conforme explicou o anarquista Cecílio Villar ao Correio do Povo, a FORGS nomeou uma Comissão de três pessoas (Salvador Rios, Luiz Derive e o próprio Villar) que escolheram dois membros de dada associação filiada para compor a Liga. A nominata ficou composta dos seguintes militantes operários: Cecílio Villar, Luis Derivi, Salvador Rios, Juvêncio Lima, Vigo Collin, Neno Martins, Adão Lopes de Souza, Carlos Toffolo, Carlos Nogueira, Marcelino dos Santos Figueiró, Orlando Martins, João Batista Moll, Abílio de Nequete, João Hoffmann, Pedro Ferrari, João R. Viegas, Antonino Dido, Francisco Guttmann e Altivo Ferreira. Na mesma ocasião, a Liga de Defesa Popular fez a seguinte Proclamação ao Povo de Porto Alegre:

A Liga de Defesa Popular, investida de poderes em solene reunião dos trabalhadores de Porto Alegre, interpretando e sentindo as condições aflitivas em que se encontram as classes populares, a braço com a carestia crescente dos gêneros de primeira necessidade e aluguéis de casas, declara que vai agir no sentido de obter algumas melhorias que Ihes possam atenuar a miséria em que se debatem.

Povo! Trabalhadores! Não é possível cruzarmos os braços e deixar que a ganância sórdida que caracteriza a época nos reduza a farrapos humanos, inconscientes, rotos e famélicos. A Liga de Defesa Popular espera apoio do povo de Porto Alegre para obter as seguintes melhorias, cuja justiça ressalta ao enunciá-las."1

Entre as medidas, encontravam-se reivindicações contra o açambarcamento do açúcar, pela diminuição do preço dos alimentos, o estabelecimento de um matadouro municipal e de mercados livres nos bairros, a obrigatoriedade da venda do pão por quilo e seu tabelamento semanal, a diminuição dos aluguéis das

8 SILVA JR. "Povo! Trabalhadores!", p. 250.

9 LOPREATO, Regina. Espírito de Revolta: a greve geral anarquista de 1917. São Paulo: Annablume, 2000, p. 29-68. FAUSTO, Boris. Trabalho Urbano e Conflito Social. São Paulo: DIFEL, 1977, p. 198.

10 Sobre a greve ver, entre outros autores: PETERSEN, Sílvia Regina Ferraz. Que a união operária seja nossa pátria: história das lutas dos operários gaúchos para construir suas organizações. Porto Alegre: Editora da UFRGS, 2001, p. 328-340.

11 Correio do Povo, Porto Alegre; 31 jul. 1917, p. 6. 
casas, o estabelecimento da passagem de bonde a 100 réis, além das tradicionais reivindicações pelo aumento de salário, pela generalização das oito horas de trabalho para os homens e seis horas para mulheres e crianças. Também foi enviado um memorial ao presidente do Estado, Borges de Medeiros, e ao intendente municipal, José Montaury, com a pauta decidida na reunião.

A greve alastrou-se rapidamente. Entre 31 de julho a 4 de agosto, boa parte da produção da cidade foi interrompida e os operários chegaram a impedir a circulação de carros, permitindo que apenas aqueles sob salvo conduto da Liga andassem livremente. No dia 2 de agosto, Borges e Montaury receberam representantes da Liga no palácio do governo. O governo estadual informou que decretaria o aumento dos operários do estado e medidas contra a exportação dos gêneros. Nos dias posteriores, os empresários foram cedendo às reivindicações, e no dia 4 a Intendência baixou decretos para controlar a venda dos alimentos. No dia 5 , o chefe de polícia chamou uma comissão da Liga para acabar com a greve. A reunião foi inconclusiva, mas boatos de que a parede fora encerrada enfraqueceu o movimento e nesse dia ele foi finalizado. ${ }^{12}$

Depois da greve, a Liga de Defesa Popular, em vez de encerrar suas atividades, ampliou-se com a entrada dos membros da FORGS. Além disso, a associação editou um jornal durante três meses, $A$ Épocha, tendo também publicado suas notícias em uma pequena coluna em $A$ Federação, principal jornal editado pelo Partido Republicano do Rio Grande do Sul. Conforme Adhemar Lourenço da Silva Júnior, a LDP teria sido uma tentativa dos anarquistas de retomar o controle do movimento operário e os militantes fizeram isso ampliando sua base de apoio para além da classe operária, incluindo reivindicações dirigidas às classes populares como o controle dos preços dos alimentos e dos aluguéis. ${ }^{13} \mathrm{O}$ que viria a acontecer depois da greve, entretanto, frustrou as expectativas desses militantes. Líderes reformistas $^{14}$ tiveram um papel mais relevante e suplantaram os libertários na FORGS e na LDP. Temas como a instalação de um Tiro de Guerra em um Atheneu Operário, construído sob o patrocínio da Intendência, eram discutidos nas reuniões, deixando alguns anarquistas, como Friedrich Knistedt, escandalizados. ${ }^{15}$

O que parece ter acontecido depois da greve foi uma tentativa de institucionalização da LDP como espaço de mediação política entre a classe trabalhadora e o governo municipal, além de uma maior estruturação interna da própria Liga. Podemos acompanhar alguns indícios disso por meio do jornal $A$ Federação, órgão oficial do PRR. No dia 18, a Coluna Operária informava que os diretores das sociedades filiadas à FORGS haviam se reunido para ouvir o relatório produzido pela LDP, que foi entregue à Federação. Nessa mesma reunião foi proposta e aprovada a entrada de todos os diretores das sociedades filiadas à FORGS na Liga de Defesa Popular. Em outra passagem, era anunciado o lançamento

12 As informações sobre a greve foram recolhidas em PETERSEN. Que a união operária seja nossa pátria, p. 328-340; SILVA JR. "Povo! Trabalhadores!", p. 302-340 e QUEIRÓS. "Estratégias e Identidades", p. 45-50.

13 SILVA JR. "Povo! Trabalhadores!", p. 264.

14 É muito difícil estabelecer a orientação política dos dirigentes da FORGS nesse momento. Refiro-me aos dirigentes da Federação Operária como sindicalistas reformistas por sua disposição de colaborar com o governo municipal e se aliar ao líder republicano Francisco Xavier da Costa, mas também por colocá-los em oposição aos anarquistas, que eram adeptos do sindicalismo revolucionário como forma de afastar dos sindicatos as lideranças socialistas e oriundas de outras correntes políticas que tivessem a perspectiva de colaboração e participação na estrutura do Estado. Sobre os anarquistas e o sindicalismo revolucionário, ver OLIVEIRA, Tiago Bernardon de. "Anarquismo, sindicatos e revolução no Brasil (1906-1937)" (Tese de doutorado em História, Universidade Federal Fluminense, 2009).

15 KNIESTEDT, Friedrich. Memórias de um Imigrante Anarquista. Tradução, introdução, epílogo e notas de rodapé: René E GERTZ. Porto Alegre: Escola Superior de Teologia e Espiritualidade Franciscana, 1989, p. 123. 
na próxima segunda-feira, dia 20 de agosto, do jornal da LDP A Épocha, periódico "de feitio sindicalista" voltado para as questões econômicas. Na mesma coluna, era informada também a realização de uma reunião promovida pela subcomissão da Liga de Defesa Popular do Bairro Navegante para organizar as categorias de trabalhadores daquele arrabalde. ${ }^{16}$

Quanto às relações com o Estado, a instalação dos mercados municipais propiciou um espaço de colaboração da LDP com a municipalidade. Logo após o final da paralisação, no dia 11 de agosto, uma comissão da Liga foi até o intendente José Montaury, que afirmou cogitar a implantação dos mercados livres, o que havia sido uma das pautas da Greve Geral. ${ }^{17}$ No dia 25 de agosto, foi publicado um decreto assinado pelo intendente que criava as feiras e mercados livres no município de Porto Alegre, em texto que citava textualmente o "alvitre sugerido pela comissão central da Liga de Defesa Popular". ${ }^{18}$ No dia 31 de agosto, A Federação publicou um novo boletim da LDP, em que eram comentadas as vantagens da instalação dos mercados para a população de Porto Alegre. ${ }^{19}$ Alguns dias depois da inauguração, o mesmo jornal comentava a inauguração do primeiro mercado no Arrabalde Navegante, comentando inclusive que esses estavam organizados de tal forma a impedir qualquer forma de fraude, pois "os poderes municipais, auxiliados por uma comissão da Liga de Defesa Popular, exercem rigorosa fiscalização sobre o comércio dos mercados". ${ }^{20}$

Tudo isso desgastou as relações entre os anarquistas que se agrupavam na União Operária Internacional (UOI) e a FORGS, de cuja UOI se retirou em princípios de 1918. Nesse ambiente de cizânia e ataques mútuos é que aparecerá o jornal A Luta, em março, porta-voz dos anarquistas contra os sindicalistas reformistas e os dirigentes da FORGS. Pelas páginas do A Luta pode-se entender um pouco melhor a lógica das dissensões que ocorreram dentro da LDP e mesmo o que vinha ocorrendo antes da greve de agosto. No primeiro número, de 28 de março, a União Operária Internacional se defendia das "intrigas" que lhe haviam sido movidas. Na verdade, o jornal ataca dois dirigentes da FORGS, Plínio de Freitas e Antônio Macedo, que acusam de estar em contato com políticos "trocando a independência do movimento por favores concedidos aos governantes, a autonomia do movimento por Atheneus e Tiros operários". ${ }^{21}$

A ideia de construir um Atheneu Operário onde seriam ministradas aulas para os trabalhadores era um projeto antigo do movimento operário de Porto Alegre, tendo o projeto sido apresentado no começo da década de 1910. A construção havia sido iniciada, mas fora interrompida diversas vezes por falta de recursos. Essa questão era retomada por Freitas e Macedo, sendo que os dois dirigentes aproximavam-se de Xavier da Costa, agora conselheiro municipal, e encampavam a plataforma da construção do Atheneu sob o patrocínio da Intendência. Xavier da Costa apresentou o projeto no Conselho Municipal em 23 de novembro de 1917, propondo ao intendente realizar um acordo com a FORGS para que o governo municipal concluísse o prédio, desde que a Federação oferecesse aulas noturnas gratuitas para os trabalhadores e seus filhos. ${ }^{22}$ Pelo que denunciaram depois os anarquistas, a proposta original também abrangia a instalação de um Tiro de

16 A Federação, Porto Alegre, 18 ago. 1917, p. 1.

17 A Federação, Porto Alegre, 13 ago. 1917, p. 3.

18 A Federação, Porto Alegre, 25 ago. 1917, p. 7.

19 A Federação, Porto Alegre, 31 ago. 1917, p. 7.

20 A Federação, Porto Alegre, 12 set. 1917, p. 6.

21 A Luta, Porto Alegre, 28 mar. 1918, p. 2.

22 SCHMIDT. Em busca da terra da promissão, p. 337. 
Guerra no prédio (o Brasil estava prestes a entrar na Primeira Guerra Mundial contra a Alemanha e seus aliados), o que deve ter chocado imensamente os militantes libertários, pois estes eram históricos defensores do antimilitarismo e do internacionalismo.

Ao que tudo indica, a Liga de Defesa Popular foi um lugar muito propício para articular a aproximação dos dirigentes da FORGS com o conselheiro Francisco Xavier da Costa, já que a LDP havia se colocado como um canal de comunicação entre os trabalhadores e o governo municipal. No segundo número do jornal $A$ Luta, de $1^{\circ}$ de maio, no texto "Desmascarando Tartufos" são caracterizados os dois dirigentes: Antônio Macedo era um linotipista vindo do Rio de Janeiro para furar uma greve do Correio do Povo; esse seria um tipo que fingia mansidão para provocar divisões no movimento operário. Plínio de Freitas era um ex-maragato que se tornara governista "por cálculo" e que tinha por objetivo se tornar um cabo político entre os trabalhadores. Estes atacariam a UOI por ela não compactuar com os planos deles, de se aproximar do governo por intermédio do conselheiro Xavier da Costa.

\begin{abstract}
Valeram-se do fato de que três operários que em tempo haviam pertencido à Internacional terem se tornado funcionários públicos, procuraram os intrigantes jogar sobre todos baldões infamantes que os desmoralizassem e isto com o fim de afastar do seu caminho quem pode lhe arrancar a máscara que lhe cobre a focinheira. ${ }^{23}$
\end{abstract}

Essas acusações remontam ao início da história da Liga de Defesa Popular. A greve foi encerrada depois de uma reunião entre representantes da Liga e da Intendência. Da reunião participaram anarquistas históricos como Zenon de Almeida, Cecílio Villar e Polidoro Santos. Depois desse episódio, a greve perdeu força, pois alguns membros da Liga teriam recomendado aos trabalhadores o retorno ao trabalho. A partir desse fato espalhou-se um boato sobre a traição.

\footnotetext{
Ainda que o acordo estivesse elaborado, alguns membros do comitê deram o sinal para a retomada de trabalho. Quando Polydoro deixou a prefeitura, seis horas depois, a greve estava parcialmente perdida. Naturalmente espalhou-se que uma parte dos membros do comitê fora subornada pelos empresários e pela administração municipal, entre eles Cecílio Villar e Zenon de Almeida. O movimento operário sofrera um forte baque, ainda em 1918 sentíamos os efeitos. As reuniões de mobilização, de ataque e de defesa, não acabavam mais. ${ }^{24}$
}

Como é possível observar pelas páginas do A Luta, a essa acusação juntou-se outra, quando alguns daqueles operários conseguiram empregar-se na Intendência Municipal. Um dos operários era Cecílio Villar, que participara da comissão de negociação com o governo. Provavelmente muitos inimigos políticos de Villar devem ter ligado o episódio do fim da paralisação ao emprego na Intendência, o que confirmaria o tal suborno. Um pequeno necrológio desse operário, que morreu em 1918, lembra o caso: "Mais tarde, para gáudio de seus detratores, quis a fatalidade que se oferecesse oportunidade de Villar se empregar na Intendência Municipal. Não resta dúvida, o caso foi sensacional". ${ }^{25}$ 
Podemos fazer até um exercício de imaginação histórica e pensar o quanto os militantes próximos de Xavier da Costa não devem ter coberto os anarquistas de sarcasmo, anos depois de estes terem atacado o líder socialista por sua aproximação com os poderes públicos. Claro, não é o mesmo conseguir um emprego na Intendência e se tornar conselheiro municipal, mas deve ter dado oportunidade para atingir a moral das lideranças libertárias.

Não se deve, entretanto, aderir incondicionalmente à versão dada pelo $A$ Luta. O jornal era um órgão de combate dos anarquistas, possivelmente teríamos outra versão dos fatos se as opiniões de Antônio Macedo ou Plínio de Freitas fossem conhecidas. O que fica de substancial para a análise da LDP é a constatação que esta era uma associação marcada pela divisão interna e pelo ressurgimento das disputas que haviam marcado o movimento operário nos anos de 1900. Francisco Xavier da Costa, que já estava no Partido Republicano, ao que parece não perdera completamente sua influência entre os operários, podendo agir junto aos dirigentes da FORGS e da LDP para tentar desempenhar o papel de canal entre esses e a Intendência Municipal. Não fica claro se os dirigentes reformistas, antes mesmo da greve, tinham Xavier da Costa como referência política, mas depois do episódio isso parece ser evidente.

\section{A LDP como campo de disputa política}

É muito provável que a divisão interna da LDP não tenha surgido com a entrada dos dirigentes da FORGS na Liga, mas tenha acontecido na fundação da mesma. Pode-se perceber que os anarquistas não controlaram completamente a associação desde o início pela trajetória de alguns dos nomes presentes na sua fundação. Um destes é o alfaiate Vigo Collin.

O nome de Vigo Thompson Collin aparece pela primeira vez no dia de 31 de julho de 1917, como um dos dezenove integrantes da recém-formada Liga de Defesa Popular. Seu nome é destacado também no memorando que a Liga enviara ao presidente do Estado, Borges de Medeiros, pedindo medidas contra a elevação dos preços dos alimentos, os preços dos aluguéis das casas e os baixos salários que os trabalhadores recebiam. Vigo Collin, juntamente com João Batista Moll e Cecílio Villar, era um dos três operários que assinaram essa pauta de reivindicações em nome de toda a Liga, e até certo ponto, em nome de todo povo de Porto Alegre, pelo qual a Liga pretendia falar.

Friedrich Kniestedt afirma, em suas memórias, que os debates que ocorreram depois da greve pela instalação de um Tiro de Guerra no edifício da Federação (muito provavelmente se referisse ao Atheneu Operário, cujo prédio, depois que terminasse sua construção, abrigaria também a sede da Federação) tinham como defensores, além de Plínio de Freitas e Antônio Vieira de Macedo, Xavier da Costa e Vigo Collin. ${ }^{26}$ Ou seja, um membro importante da Liga (se supõe pela assinatura do memorando a Borges) que havia sido criada sob influência dos anarquistas, depois da greve alinhou-se com o antigo inimigo destes, Xavier da Costa, e com os dirigentes reformistas da Federação.

Vigo Collin seria eleito, em maio de 1918, presidente da Federação Operária do Rio Grande do Sul, integrando sua diretoria juntamente com João Huber e Juvêncio Lima. Os três diretores eram oriundos da LDP. Tratava-se de uma 
mudança de postura desses sindicalistas? Talvez não. Em depoimento a Benito Schmidt, Anita Xavier da Costa, filha do antigo líder socialista, explicou a estreita ligação que Collin tinha com Francisco: "(...) era o alfaiate do meu pai. Ele tinha uma grande admiração pelo meu pai, até meio exagerada. Quando meu pai chegava a sua alfaiataria, ele dizia: 'O meu conselheiro'. Meu pai dizia: 'Calma, um dia eu ainda posso ser preso e tu vais se complicar..."'27

Outra liderança não anarquista participante da fundação da Liga foi Abílio de Nequete. Abílio era um barbeiro libanês e, conforme o caderno de memórias que ele mesmo escreveu, sua primeira experiência no movimento operário foi na LDP. Posteriormente ele se tornaria inclusive o diretor do jornal que o grupo editava, chamado de A Épocha. Nequete tinha uma interpretação bastante particular do movimento operário, sendo um grande admirador da Revolução Russa e da Rússia Revolucionária, devido a suas origens étnicas e religiosas. ${ }^{28}$

Depois da greve e da atuação no jornal, Nequete começou a promover reuniões na sua casa e escreveu um panfleto intitulado "Ao povo rio-grandense" e assinado por um "Grupo de Operários e Soldados", que distribuiu entre militares de um quartel da capital. Preso e submetido a um inquérito policial militar, ele declarou que havia produzido aquele documento no intuito de unir os dois grupos sociais, já que a vida na caserna era muito mal vista pelos trabalhadores. Logo depois, Abílio de Nequete se juntaria aos anarquistas da União Operária Internacional, que faziam uma dura oposição aos sindicalistas reformistas e às lideranças republicanas.

Nequete, pela sua profissão, devia ser conhecido e sendo ele um autodidata que lia muito, isso deve tê-lo qualificado para ocupar a posição de editor do periódico. Independente desse fato, devem ter existido outros Nequetes na LDP, operários sem experiência sindical que tiveram na greve geral e nas reuniões da Liga a primeira chance de atuar como militantes, depois de um grande período de dormência do movimento. Também deve ter havido outros Collins, aliados de Xavier da Costa ou trabalhadores reformistas aos quais seria imoral, ou mesmo imprudente, por parte dos organizadores anarquistas impedir sua participação na nova organização.

Dessa forma, a Liga aparece como uma "frente ampla" dentro do movimento operário, onde, apesar da clara predominância anarquista, era necessário incluir outros militantes para legitimar suas ações. A formação dessa frente tem uma razão óbvia: a FORGS que deveria desempenhar o papel de agregação das sociedades operárias não se comprometeu com o movimento paredista de 1917, e a UOI, que se comprometia, não tinha tanto prestígio, devendo estar, pela lógica organizativa, submetida à FORGS. Por mais força que tivessem os militantes anarquistas eles não podiam ampliar sua influência ou iniciar um grande movimento apenas com a velha Internacional; por outro lado, uma Federação inativa e sem compromisso com uma mobilização de massa era um obstáculo difícil de transpor.

Foi nesse contexto que a Liga surgiu como possibilidade de formar um organismo mais amplo, tão mais amplo que buscou legitimidade nas classes populares e não somente no operariado; mas a formação de uma "frente" como essa requeria necessariamente a inclusão de operários não anarquistas e mesmo antipáticos a eles, como devia ser o caso dos aliados de Xavier da Costa para compor sua nominata. De qualquer forma, apesar dessa tática anarquista ser fundamental para compreender o surgimento da LDP, acredito que não se possa justificar a

27 SCHMIDT. Em busca da terra da promissão, p. 339.

28 BARTZ, Frederico Duarte. "Abílio de Nequete (1888-1960): os múltiplos caminhos de uma militância operária". História Social , Campinas, v. 14/15, p. 157-173, 2008. 
formação da Liga somente pelo desejo de controlar o movimento operário: mesmo mitigando-se os efeitos da carestia, como fez Adhemar Lourenço da Silva Júnior, ${ }^{29}$ não se pode esquecer a extensão que a paralisação teve e de quão rapidamente espalhou-se, sinal que as palavras de ordem dos libertários sobre miséria tinham uma correspondência forte com a realidade.

Os dirigentes da FORGS estavam fora da lista de nomes da LDP, o que não surpreende se pensarmos que ela havia sido criada em oposição à direção. Apesar disso, surpreende também que anarquistas históricos como Zenon de Almeida e Polydoro Santos não estivessem com seus nomes ali. Talvez porque a Liga fosse dominada pelos libertários, mas não deveria parecer dominada pelos libertários, só assim conseguindo legitimidade para alçar-se acima da Federação, como de fato se alçou. Diferente da UOI, ela não deveria apresentar uma identidade política tão bem definida.

Mesmo assim, essa lista de nomes parece ter sido mais pró-forma do que real. Conforme Knistedt, a comissão da LDP que negociou o fim da greve tinha entre seus membros Zenon de Almeida e Polydoro Santos. ${ }^{30}$ Isso faz crer que a Liga deve ter-se expandido durante a greve, entrando nela os dirigentes anarquistas que formalmente ficaram de fora. Se isso aconteceu, a incorporação também dos dirigentes da Federação logo em seguida deve ter seguido a lógica de associação abrangente na qual a Liga surgiu. Mas ao fim e ao cabo, a lógica desse instrumento de mobilização de massas, que permitiu aos anarquistas colocarem-se na linha de frente da paralisação, por cima da FORGS, acabou por ser também sua perdição. Não se poderia impedir os dirigentes da Federação de fazer parte da associação criada para gerir a greve se eles entrassem na greve, como de fato entraram. 0 fato é que depois de acabada a greve a atitude de beneplácito dos administradores do PRR (Partido Republicano Rio-grandense) em relação aos operários pode ter sido a oportunidade de ouro para Xavier da Costa e quem o apoiava simplesmente recolher as glórias das conquistas resultantes do movimento.

Miguel Bodea apresenta as ações de Borges de Medeiros entre os operários como um pré-populismo, um primeiro experimento de tentativa de legitimação por parte um governo elitista e oligárquico por meio do apoio popular. Suas ações a favor dos trabalhadores de Porto Alegre viriam ao encontro dos seus objetivos eleitorais naquele ano, além de ter sido feita a expensas dos grandes fazendeiros organizados no Partido Federalista, favorecidos pelo açambarcamento de gêneros alimentícios. Bodea chega mesmo a falar em uma aliança para baixo dos setores médios e oligarquias dissidentes representados pelo PRR com os setores populares. ${ }^{31}$ Tendo ou não fim imediatamente político, a ação governamental serviu como refrator de uma tendência de radicalização representada inicialmente pela LDP, pela qual os aliados de Xavier da Costa obtiveram o controle da associação.

Por seu turno, o conselheiro Xavier da Costa tentava desempenhar o papel de porta-voz dos operários no Conselho Municipal. Em novembro ele propôs, no Conselho Municipal, a autorização para a Intendência fazer um acordo com a FORGS para ajudar na construção do Atheneu Operário, em troca da Federação assumir o compromisso de oferecer aulas gratuitas noturnas para os operários. Em dezembro a proposta foi rejeitada, provocando a indignação do conselheiro Xavier da Costa. Esse fato demonstra que mesmo havendo apoio dos operários a determinado grupo político ou que esses depositassem esperança na ação do

29 SILVA JR. "Povo! Trabalhadores!", p. 244-248.

30 KNIESTEDT. Memórias de um Imigrante Anarquista, p. 124.

31 BODEA. A greve de 1917, p. 17. 
Estado, não havia garantias de que o Estado correspondesse às expectativas. ${ }^{32}$

Como mostrei anteriormente, depois da greve, a relação entre a FORGS e a LDP se tornou um tanto obscura, já que a entrada dos líderes da Federação tornaria as duas entidades permeáveis uma a outra. De qualquer forma, uma coisa pode ser afirmada com certeza: os libertários perderam muita força política depois da greve. Conforme sua versão, os aliados de Xavier da Costa teriam se "aproveitado" do pouco conhecimento dos outros militantes para influenciá-los, ou como coloca A Luta: "Os delegados, alguns novos, surpresos, surgidos na última greve, deixamse embair...".33 Quem estendeu sua influência sobre um novo contingente de militantes, mobilizados pela LDP, foram os aliados do conselheiro republicano, e não os anarquistas, que tiveram de recuar.

Não só tiveram de recuar, como foram atacados. Apesar das poucas informações que existem sobre os primeiros meses de 1918, tudo indica que os dirigentes da FORGS teriam partido para uma ofensiva contra os anarquistas. Conforme o jornal A Luta, de 28 de março, os dirigentes da Federação Operária teriam publicado um panfleto contra os membros da UOI. O processo culminou com o desligamento da União Operária Internacional da FORGS no dia 13 de março, mas a associação não se retirou da LDP. Fora da FORGS, as principais lideranças anarquistas encontraram na Liga de Defesa Popular um campo aberto para enfrentar os dirigentes da Federação que Ihe moviam uma campanha antianarquista: Antônio Macedo e Plínio Freitas. A LDP desempenhou então um terceiro e último papel na história do movimento operário: depois de ter servido aos anarquistas para incitar a greve e de ter sido ponto de apoio para os aliados de Xavier de Costa estenderem sua influência sobre os trabalhadores organizados, ela se apresentava como campo de luta entre as duas tendências em que se viu dividido o movimento operário em Porto Alegre.

Nesse sentido, a LDP se transformou no lugar onde os dirigentes da UOI podiam responder aos da FORGS. Quatro dias depois de se desligar da FORGS, no dia 17 de março de 1918, os anarquistas chamaram uma reunião dos membros da LDP no salão da Sociedade Helena de Montenegro para se defender das acusações da diretoria. Compareceram 18 membros da Liga, mas os diretores da Federação não participaram, de modo que os membros da LDP encaminharam esta moção: "Os membros da Liga de Defesa Popular, reunidos a convite da U. O. Internacional, não reconhecem razão alguma na acusação feita pela atual diretoria contra os sócios da U. O. Internacional". ${ }^{34}$ Pelas páginas do A Luta, os militantes da UOI responderam duramente aos sindicalistas reformistas:

Ficou assim pulverizada e reduzida às suas justas e mesquinhas proporções a infâmia com que o prepotente grupinho politiqueiro pretendeu desmoralizar seus desafetos.

O povo operário que julgue: de um lado nós, os da Internacional, mantendo nossos princípios de pé, nos opondo ao desgarramento do proletariado para a política, fonte de divergências e de discórdias; de outro lado: um grupinho de bajuladores querendo a todo transe arrastar os trabalhadores para o terreno resvaladiço da política, trocando a independência operária por favores concedidos pelos governantes, abdicando de sua autonomia em troca de Ateneus e Tiros operários. ${ }^{35}$

32 Posteriormente a proposta de auxílio foi modificada, tornando-se mais abrangente e não se dirigindo especificamente à FORGS, tendo sido finalmente aprovada. SCHMIDT. Em busca da terra da promissão, p. 337.

33 A Luta, Porto Alegre, $1^{\circ}$ maio 1918, p. 3.

34 A Luta, Porto Alegre, $1^{\circ}$ maio 1918, p. 3.

35 A Luta, Porto Alegre, 28 mar. 1918, p. 1. 
Ainda se teria reforçado essa posição numa declaração aprovada na mesma reunião da Liga de Defesa Popular, que pode ser tomada como uma censura contra os dirigentes da Federação Operária:

\begin{abstract}
Todos os trabalhadores aqui presentes reconhecem que a pretensa diretoria da F. O. do R. G. do Sul não tem provas morais ou materiais do que afirmou em boletim; que a federação com a atual "diretoria" que desvirtua os seus princípios não representa o operariado consciente; que portanto usurpa o sinete do $2^{\circ}$ Congresso Operário porque de seus princípios se desviou, pretendendo criar linhas de tiro, etc.

E ainda que os presentes reconheçam a improcedência das acusações da referida diretoria que não tem idoneidade moral para julgar os atos da UOI ou a quem quer que seja. ${ }^{36}$
\end{abstract}

O caráter de uma frente ampla e sem definição política servia agora aos anarquistas para abrigarem-se dos ataques dos dirigentes da Federação, já que estes não poderiam dar àquele organismo o caráter antianarquista que haviam imprimido à FORGS. Mais do que isso, os anarquistas da União Operária Internacional agora utilizavam a Liga de Defesa Popular para atacar os dirigentes da Federação, tirando parte de sua legitimidade diante do proletariado da capital.

Em $1^{\circ}$ de maio de 1918, A Luta não trouxe mais informações sobre a LDP. Naquela data ocorreriam graves conflitos entre militantes da UOI e do Sindicato dos Canteiros por um lado, e militantes da FORGS por outro. ${ }^{37}$ Depois dessa data surgiria a União Geral dos Trabalhadores, construída pelos anarquistas para ser uma nova federação sindical. A experiência da LDP deve ter levado os anarquistas a pensar seriamente quanto ao tipo de organismo que desejariam criar; em vez de uma Liga sem definição ideológica que poderia conviver com uma Federação, resolveram fundar uma União com princípios sindicalistas mais definidos, para ser uma alternativa à FORGS. A situação do movimento era diferente do inverno de 1917, as posições estavam definidas e os anarquistas partiram para o ataque. A fundação do A Luta em 28 de março era parte dessa estratégia.

A FORGS elegeu uma nova diretoria, com Vigo Collin, Juvêncio Lima e João Hubert, todos egressos da LDP como havia frisado antes. A situação dos operários ainda era grave, pela falta de gêneros de primeira necessidade nos mercados. No dia 18 de julho, meses depois da fundação, a UGT se reuniu juntamente com a FORGS e a União Metalúrgica para decidirem o que fazer diante das difíceis condições dos trabalhadores. Dias antes, a FORGS telegrafara ao presidente Wenceslau Brás pedindo sua intervenção na questão dos preços, e diante de boatos sobre uma nova greve, o presidente Collin esclareceu à imprensa que esperava a resposta do presidente da República para decidir sobre a questão. ${ }^{38}$

Na reunião que ocorreu entre as três entidades de trabalhadores (FORGS, UGT e União Metalúrgica), os operários enviaram um memorial a Borges de Medeiros pedindo pelo combate à carestia e outras reivindicações que repetiam a pauta de 1917, mas nesse encontro a direção da Federação se demitiu coletivamente. As sociedades operárias também incitaram a greve como forma de protesto contra a miséria em que viviam. Dois dias depois, o telegrama voltou sem sequer ser aberto pelo presidente do Estado, e militantes, por certo anarquistas, aproveitam da 
ocasião para distribuir um panfleto em que mostravam o quão inútil era se dirigir ao governo para pedir alguma coisa.

Os operários entraram em greve, mas a paralisação foi duramente reprimida. Para os anarquistas esse movimento não foi uma derrota, mas uma vitória, porque a FORGS se uniria à UGT depois disso e adotaria os estatutos desta, ou seja, se transformaria em entidade sindicalista, sob a influência dos libertários. É interessante, em termos de comparação com a diretoria da FORGS que se demitiu anteriormente, analisar as palavras do presidente demissionário, o alfaiate Collin, explicando o que deveria ser feito em caso de greve "(...) o operariado se reúne em lugar previamente anunciado e aí nomeia-se ad hoc presidente e secretário, que será qualquer operário presente. Assim, doravante serão resolvidas as questões entre os operários". 39

A fórmula levantada por Collin lembrava muito o modelo de formação da LDP, em 1917. A reunião em que as principais sociedades operárias de Porto Alegre se juntaram para discutir a greve, lançando um manifesto para Borges, não lembraria também a ocasião em que se formou a LDP? Por que não surgiu uma nova Liga ou a antiga não foi reavivada como comitê permanente? Na mesma entrevista, Collin explicou porque havia se demitido:

\begin{abstract}
A missão da Federação Operária, além de tratar do interesse geral das classes operárias, é servir de intermediária entre as classes operárias, os poderes constituídos e os patrões.

A atitude manifestada pelo operariado é deliberada por assembleia dos sindicatos filiados à Federação e outras corporações, tendo os seus membros o dever de executar o que foi resolvido em assembleia. Quando os membros da diretoria encontram empecilhos no desempenho de suas missões, julguem-se incompatibilizadas com as classes trabalhadoras, e foi o que aconteceu. ${ }^{40}$
\end{abstract}

A Federação Operária deveria ser o que tinha sido a LDP e a própria FORGS quando estiveram sob o controle dos sindicalistas reformistas. A Liga se colocou como representante do povo e dos trabalhadores diante do governo em agosto, mas depois desse momento, ela assumiu também o papel de intermediária entre os trabalhadores e o governo, tendo os operários um interlocutor privilegiado nas esferas do poder: Xavier da Costa. Essa fórmula era impossível de ser repetida agora e por um motivo bem simples: havia passado mais do que um ano entre o inverno de 1917 e o inverno de 1918. No caso específico dos anarquistas, eles não deviam estar mais dispostos a formar uma ampla frente depois de tudo o que se passou após a greve; o momento era de desalojar os aliados de Xavier da Costa para que eles não voltassem tão cedo à linha de frente do movimento, o que acabou funcionando. Os operários que se organizaram na UOI são os principais líderes das greves de 1919, mas os nomes dos líderes da FORGS e da LDP no seu "segundo período" quase não aparecem. ${ }^{41}$

Também havia mudado outra coisa: a atitude do governo diante do problema operário. Apesar de toda boa vontade no período da greve, a que Miguel Bodea reputa como motivada também por interesse eleitoral, no final de 1917 já eram frustrados os planos do conselheiro Xavier no Conselho Municipal de aprovar o patrocínio da Intendência para a construção do Atheneu Operário. Em 1918, Borges

39 PETERSEN. Que a união operária seja nossa pátria, p. 344.

40 PETERSEN. Que a união operária seja nossa pátria, p. 343.

41 Sobre a greve de 1918, ver QUEIRÓS. “Estratégias e Identidades”, p. 50-59. 
deu por resolvida a questão da carestia e sequer leu o pedido das associações enviado a ele. Sem as ações do Estado, quebrava-se todo o prestígio que lastreava a diretoria da FORGS: em vez de comissões recebidas em palácio, o operariado teve "comissões" da polícia batendo em suas portas. Estava muito longe o ano de 1917 !

\section{Conclusão}

O que havia acontecido era uma intensa experiência de luta dos operários em que todos os atores envolvidos tinham passado por sucessos e fracassos, sonhos e desilusões, enorme prestígio e amargo ostracismo. O processo de luta de classe, a tentativa de construir associações, as relações com o Estado e as relações entre os grupos de operários, que não estavam dadas em um primeiro momento, foram definindo os modos desses grupos agirem, suas alianças, suas inimizades. Talvez nisso esteja a relevância de se estudar a Liga de Defesa Popular: observar uma associação que surgiu com a reestruturação do movimento operário e por suas características foi palco e instrumento das mudanças pelas quais o movimento se reestruturou. Assim, compreendendo a trajetória da LDP, poderá se entender um pouco mais da lógica do movimento operário de Porto Alegre em um momento crucial de sua história.

Recebido em 10/06/2015

Aprovado em 18/12/2016 